\title{
Assessment of Undiscovered Oil and Gas Resources of the Volga-Ural Region Province, Russia and Kazakhstan, 2010
}

\begin{abstract}
The U.S. Geological Survey estimated mean volumes of technically recoverable, conventional, undiscovered petroleum resources at 1.4 billion barrels of crude oil, 2.4 trillion cubic feet of natural gas, and 85 million barrels of natural gas liquids for the Volga-Ural Region Province, using a geology-based assessment methodology.
\end{abstract}

\section{Introduction}

The U.S. Geological Survey (USGS) estimated technically recoverable, conventional, undiscovered oil and gas resources of the Volga-Ural Region Province in Russia and Kazakhstan as part of a program to estimate these resources for priority basins around the world. The province encompasses approximately 725,000 square kilometers (fig. 1), north of the Caspian Sea. This assessment was based on published geologic information and on commercial data from oil and gas wells and fields, and field production records. The USGS approach is to define total petroleum systems and assessment units, and assess the potential for undiscovered oil and gas resources.

\section{Total Petroleum Systems and Assessment Units}

Two total petroleum systems (TPS), the Proterozoic-Paleozoic Composite and the Permian Foreland Basin, were defined for the Volga-Ural Region Province (table 1). The ProterozoicPaleozoic Composite TPS was defined to include petroleum source rocks ranging in age from Late Proterozoic through Carboniferous, with Upper Devonian to Lower Carboniferous (middle Frasnian to Tournasian) Domanik mudstone being the main source of petroleum. Two assessment units (AU) were defined geologically within the Proterozoic-Paleozoic Composite TPS - Volga-Ural Clastic and Carbonate Reservoirs and Lower Volga (figs. 1 and 2). Reservoirs and seals in these AUs are associated with carbonate platforms and reefs, and marine clastic rocks. Middle to Upper Devonian sandstones and Lower Carboniferous carbonate rocks contain the greatest quantities of known oil and gas. Known traps include reefs, drapes over reefs, anticlines over inverted rift grabens and basin uplifts, and fault-related traps. Pinchout and stratigraphic traps also are recognized.

The Permian Foreland Basin TPS was defined to include Permian (Asselian to Artinskian) deep-water, organic-rich mudstone source rocks. One AU was defined for the Permian Foreland Basin TPS - Permian Reefs/Thrust Folds TPS (fig. 1). Reservoirs in this AU include Permian carbonate reefs and clastic rocks having evaporite seals, primarily the Lower Permian (Kungarian) evaporite. Known traps are reefs and structures associated with thrust faults and folding.

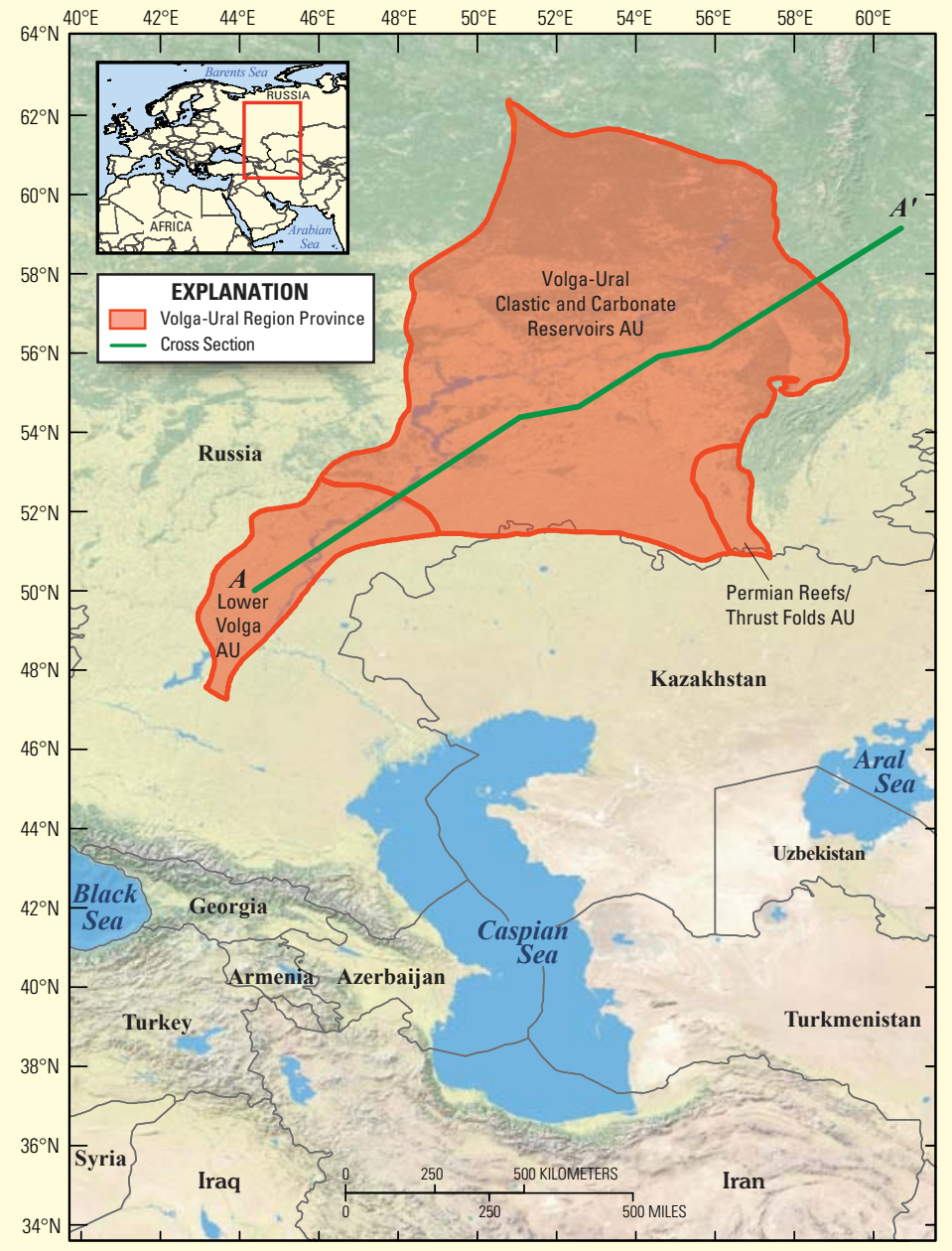

Figure 1. Location of 3 assessment units (AU) in the Volga-Ural Region Province and approximate location of cross section $(A-A)$ shown in figure 2. (Map not definitive for political boundaries.)

\section{Assessment Results}

Estimates of volumes of technically recoverable, conventional, and undiscovered oil and gas resources are shown in table 1 . No attempt was made to estimate economically recoverable resources because it is beyond the scope of this study. The mean volumes and probability ranges $\left(\mathrm{F}_{95}\right.$ to $\left.\mathrm{F}_{05}\right)$ of 


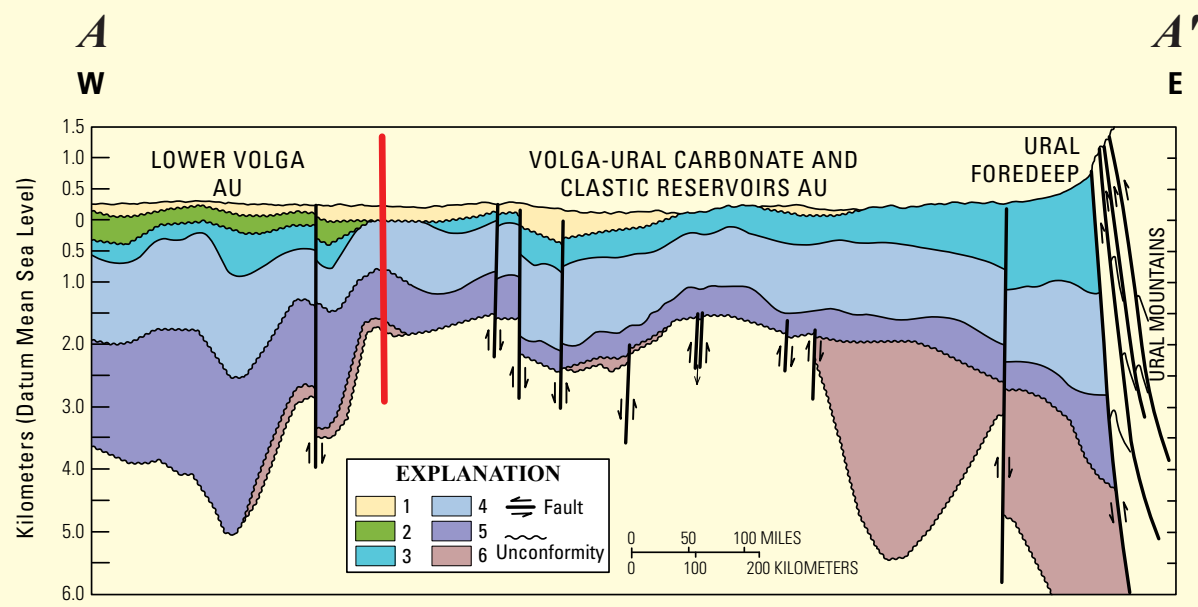

Figure 2. Schematic geologic cross section of the Volga-Ural Region Province illustrating the geologic delineations of two of the three assessment units (AU) in this study (red line). The third AU, Permian Reefs/Thrust Folds, is out of the plane of the cross section. Location of cross section is shown in figure 1. Modified from Peterson and Clarke (1983a, b). Rock units: 1, Pliocene, mostly continental clastic rocks; 2, Mesozoic, mostly continental clastic rocks; 3, Permian, continental clastic rocks and marine carbonate rocks; 4, Carboniferous, mostly marine carbonate rocks; 5 , Devonian, marine clastic and carbonate rocks; 6 , Proterozoic, marine clastic and carbonate rocks.

Table 1. Volga-Ural Region Province assessment results (technically recoverable, conventional undiscovered resources).

[MMB, million barrels; BCF, billion cubic feet. Results shown are fully risked estimates. For gas fields, all liquids are included under the natural gas liquids (NGL) category. F95 denotes a 95-percent chance of at least the amount tabulated. Other fractiles are defined similarly. Fractiles are additive under the assumption of perfect positive correlation. TPS, total petroleum system; AU, assessment unit. Gray shading indicates not applicable.]

\begin{tabular}{|c|c|c|c|c|c|c|c|c|c|c|c|c|c|c|}
\hline \multirow{3}{*}{$\begin{array}{l}\text { Total Petroleum Systems } \\
\text { (TPS) } \\
\text { and Assessment Units (AU) }\end{array}$} & \multirow{3}{*}{$\begin{array}{l}\text { Field } \\
\text { type }\end{array}$} & \multirow{3}{*}{$\begin{array}{c}\text { Mean (expected) } \\
\text { largest } \\
\text { field size } \\
\text { (MMB or BCF) }\end{array}$} & \multicolumn{12}{|c|}{ Total undiscovered resources } \\
\hline & & & \multicolumn{4}{|c|}{ Oil (MMB) } & \multicolumn{4}{|c|}{ Gas (BCF) } & \multicolumn{4}{|c|}{ NGL (MMB) } \\
\hline & & & F95 & F50 & F5 & Mean & F95 & F50 & F5 & Mean & F95 & F50 & F5 & Mean \\
\hline \multicolumn{15}{|c|}{ Volga-Ural Region Province, Proterozoic-Paleozoic Composite TPS } \\
\hline \multirow{2}{*}{$\begin{array}{l}\text { Volga-Ural Clastic and } \\
\text { Carbonate Reservoirs AU }\end{array}$} & Oil & 168 & 493 & 1,104 & 2,220 & 1,198 & 210 & 571 & 1,503 & 680 & 9 & 25 & 67 & 30 \\
\hline & Gas & 316 & & & & & 156 & 558 & 1,840 & 717 & 6 & 23 & 76 & 29 \\
\hline \multirow{2}{*}{ Lower Volga AU } & Oil & 47 & 64 & 154 & 332 & 170 & 84 & 202 & 437 & 224 & 1 & 2 & 5 & 2 \\
\hline & Gas & 196 & & & & & 158 & 432 & 1,150 & 512 & 5 & 13 & 35 & 15 \\
\hline \multicolumn{15}{|c|}{ Volga-Ural Region Province, Permian Foreland Basin TPS } \\
\hline \multirow{2}{*}{ Permian Reefs/Thrust Folds AU } & Oil & 17 & 10 & 39 & 122 & 49 & 11 & 49 & 180 & 66 & $<1$ & 2 & 8 & 3 \\
\hline & Gas & 96 & & & & & 25 & 120 & 531 & 178 & 1 & 4 & 18 & 6 \\
\hline $\begin{array}{l}\text { Total Undiscovered Petroleum } \\
\text { Resources }\end{array}$ & & & 567 & 1,297 & 2,674 & 1,417 & 644 & 1,932 & 5,641 & 2,377 & 22 & 69 & 209 & 85 \\
\hline
\end{tabular}

undiscovered petroleum are approximately 1,417 million barrels (MMB) of crude oil, with a range of 567 to $2,674 \mathrm{MMB} ; 2,377$ billion cubic feet (BCF) of natural gas (both associated and dissolved, and nonassociated), with a range of 644 to 5,641 BCF; and $85 \mathrm{MMB}$ of natural gas liquids, with a range of 22 to 209 MMB.

\section{References Cited}

Peterson, J.A., and Clarke, J.W., 1983a, Geology of the VolgaUral Province and detailed description of the Romashkino and Arlan oil fields: U.S. Geological Survey Open-File Report 83-711, $90 \mathrm{p}$.

Peterson, J.A., and Clarke, J.W., 1983b, Petroleum geology and resources of the Volga-Ural Province, U.S.S.R.: U.S. Geological Survey Circular 885, 27 p.

\section{For Further Information}

Publications detailing the geology and the methodology for the Volga-Ural Region Province and assessment results are available at the USGS Energy Program Web site, http://energy. cr.usgs.gov/oilgas/.

\section{Volga-Ural Region Province Assessment Team}

T.R. Klett (tklett@usgs.gov), Christopher J. Schenk, Ronald R. Charpentier, Michael E. Brownfield, Janet K. Pitman, Troy A. Cook, and Marilyn E. Tennyson.

\section{Acknowledgments}

Geographic Information Systems support by Christopher P. Anderson, ATA Services. Graphic support by Wayne Husband, ATA Services. 